\title{
Radium interference during radon measurements in water: comparison of one- and two-phase liquid scintillation counting
}

\author{
Ivana Stojković ${ }^{1}$, Nataša Todorović ${ }^{2}$, and Jovana Nikolov ${ }^{2}$ \\ ${ }^{1}$ University of Novi Sad Faculty of Technical Sciences, Department of Fundamentals Sciences, Novi Sad, Serbia \\ ${ }^{2}$ University of Novi Sad Faculty of Sciences, Department of Physics, Novi Sad, Serbia
}

[Received in August 2020; Similarity Check in August 2020; Accepted in September 2021]

\begin{abstract}
Assessment of radiation exposure to drinking, surface, and groundwater and of the associated health risks calls for accurate and precise ${ }^{226} \mathrm{Ra}$ and ${ }^{222} \mathrm{Rn}$ measurements. One method that fits the bill is liquid scintillation counting (LSC), which allows measurements in onephase (homogenous) or two-phase samples. The aim of our study was to compare the measurement efficiency with both variations in Niška Banja spa water, known for its elevated ${ }^{222} \mathrm{Rn}$ content to get a better insight into the stability and behaviour of the samples and ${ }^{226} \mathrm{Ra}$ interference in samples spiked with ${ }^{226} \mathrm{Ra}$ with ${ }^{222} \mathrm{Rn}$ measurement. ${ }^{226} \mathrm{Ra}$ interference was more evident in homogenous, one-phase and much lower in two-phase samples. However, one-phase samples offer more accurate indirect ${ }^{226}$ Ra measurements. Water-immiscible cocktails (in two-phase samples) have shown a limited capacity for receiving ${ }^{222} \mathrm{Rn}$ generated by Ra decay from the aqueous to organic phase when ${ }^{222} \mathrm{Rn} /{ }^{22} 6 \mathrm{Ra}$ equilibrium is reached. We have also learned that samples with naturally high ${ }^{222} \mathrm{Rn}$ content should not be spiked with ${ }^{226} \mathrm{Ra}$ activities higher than the ones found in native samples and that calibration of two-phase samples can be rather challenging if measurements span over longer time. Further research would require much lower ${ }^{226} \mathrm{Ra}$ activities for spiking to provide more practical answers to questions arising from the demonstrated phenomena.
\end{abstract}

KEY WORDS: LSC; one-phase/two-phase method; Quantulus $1220^{\mathrm{TM}} ;{ }^{222} \mathrm{Rn}$ in water; ${ }^{226} \mathrm{Ra}$ in water

Considering radiological concerns for humans, the most serious threats come from radon ${ }^{222} \mathrm{Rn}$ presence in the air, while minor doses can be received from cosmic rays, naturally present radionuclides in the Earth's crust, and artificial radionuclides emitted by power plants or medical instruments. Elevated content of naturally occurring radioactive isotopes from the ${ }^{238} \mathrm{U}$ and ${ }^{232} \mathrm{Th}$ series (dominantly their respective progenies ${ }^{226} \mathrm{Ra}$ and ${ }^{228} \mathrm{Ra}$ ) can be detected even in drinking water, and ingestion of such water is considered potential irradiation risk to human health. It has been determined that ${ }^{226} \mathrm{Ra}$ deposits in the bones and the urinary bladder and increased ${ }^{226} \mathrm{Ra}$ concentrations in drinking water increase the rates of the bladder carcinoma in men and breast cancer and lung cancer in both sexes (1). If tap water contains ${ }^{226} \mathrm{Ra}$ concentrations $>110 \mathrm{mBq} / \mathrm{L}$, mortality rate due to bone cancer significantly increases (2), while the incidence of leukaemia correlates with ${ }^{226} \mathrm{Ra}$ concentrations $>185 \mathrm{mBq} / \mathrm{L}$ in groundwater (3). In turn, ${ }^{222} \mathrm{Rn}$ in drinking water increases human exposure through inhalation (due to dissolved Rn emanation from water) and directly through ingestion. Inhalation of $\mathrm{Rn}$ progenies is associated primarily with the increased risk of lung cancer (estimated to account for $89 \%$ of water Rnrelated cancer incidences), while ingestion exposure is

Corresponding author: Ivana Stojković, $\mathrm{PhD}$, University of Novi Sad Faculty of Technical Sciences, Department of Fundamentals Sciences, Trg Dositeja Obradovića 6,21000 Novi Sad, Serbia,E-mail: ivana_st@uns.ac.rs associated primarily with the elevated risk of colon, liver, and other gastrointestinal tract cancers (estimated to account for $11 \%$ of water Rn-related cancer incidences) $(4,5)$. All this suggests that ${ }^{226} \mathrm{Ra}$ and ${ }^{222} \mathrm{Rn}$ measurement in drinking water needs to be as accurate and precise as possible to fully access radiological risks and radiation doses received through ingestion and inhalation.

One method that fits the bill is liquid scintillation counting (LSC). It is the most sensitive, widely used, reliable, effective, and suitable method for ${ }^{222} \mathrm{Rn}$ and ${ }^{226} \mathrm{Ra}$ measurement and a variety of purposes, from drinking water monitoring and groundwater radiological assessment to environmental tracer research (6-8). LSC can measure Ra indirectly through ${ }^{222} \mathrm{Rn}$ measurement, since ${ }^{222} \mathrm{Rn}$ is generated by ${ }^{226} \mathrm{Ra}$ decay inside a scintillation vial and spontaneously extracted to a water-immiscible scintillation cocktail from the aqueous phase (6). Currently the most popular technique for ${ }^{226} \mathrm{Ra}$ determination is low background LSC coupled to $\alpha / \beta$ discrimination (9). A recent comparison of various analytical methods applied to determine ${ }^{226} \mathrm{Ra}$ in water (alpha, gamma, and liquid scintillation spectrometry) singled out LSC measurements of ${ }^{226} \mathrm{Ra}$ and ${ }^{228} \mathrm{Ra}$ on Quantulus 1220 as the most accurate (10).

Although $\mathrm{Rn}$ is Ra progeny, $\mathrm{Ra} / \mathrm{Rn}$ ratio in groundwater is influenced by Ra concentration in the aquifer rock and Rn emanation coefficient (which depends on temperature and the permeability, organic component, grain size, 
porosity, moisture content, and internal structure of the aquifer) (11). This ratio tends to strongly favour $\mathrm{Ra}$ in groundwater resting on crystalline rocks, which is attributed to geochemical conditions that preferentially mobilise $\mathrm{U}$ and/or $\mathrm{Ra}$ and to the inert nature of ${ }^{222} \mathrm{Rn}(11,12)$. Considering that Ra may interfere with the Rn spectra, measurements in waters with higher ${ }^{226} \mathrm{Ra}$ and lower ${ }^{222} \mathrm{Rn}$ content may be prone to error and should take into account variability in the $\mathrm{Ra} / \mathrm{Rn}$ ratio (whether they are in equilibrium or not).

There are two variations of LSC for ${ }^{222} \mathrm{Rn} /{ }^{226} \mathrm{Ra}$ determination - one- and two-phase - which depends on whether the water in a sample is mixed with (emulsified) or separated from the scintillation cocktail. Both are highly sensitive, accurate, and precise, and involve very simple and inexpensive preparation and quick automatic counting of a large number of samples (sample counting time is a few hours maximum, typically about one hour) $(9,13)$.

The one-phase LSC uses an emulsifying cocktail which ensures sample stability over time but also involves a risk of quenching and interference of other radionuclides naturally present in such homogeneous mixtures (such as ${ }^{226} \mathrm{Ra}$ ) with the Rn spectra (14).

The two-phase LSC uses a water-immiscible cocktail, which means that Rn migrates to the organic phase for which it has greater affinity, while more hydrophilic radionuclides such as ${ }^{226} \mathrm{Ra}$ remain in the liquid phase (water) and do not interfere with or have a quenching effect on the measurement (11). An obvious advantage over the one-phase method is that these other radionuclides will not cause erratic ${ }^{222} \mathrm{Rn}$ readings, especially in samples with ${ }^{222} \mathrm{Rn}$ levels below those of other radionuclides (15). The disadvantage is that the transfer of ${ }^{222} \mathrm{Rn}$ into the cocktail (organic phase) may be incomplete, which slightly diminishes its detection efficiency (15). Regardless on the measurement method, it should be mentioned that ${ }^{222} \mathrm{Rn}$ activity is often dominant over all other radionuclides in real water samples $(5,8,12,14)$.

The main intent of this research was to investigate to what extent would ${ }^{226} \mathrm{Ra}$ interfere with ${ }^{222} \mathrm{Rn}$ water measurements with LSC in one- and two-phase samples. The idea was to examine the stability of these samples over two months and compare the performance (in terms of accuracy and reliability) of both variants in indirect determination of ${ }^{226} \mathrm{Ra}$ in water (through ${ }^{222} \mathrm{Rn}$ progeny measurement). Although there are many studies evaluating these LSC variants and their practical application, none has yet attempted to evaluate both based on activity concentrations in samples over two months.

\section{MATERIALS AND METHODS}

For this purpose we collected water from the public fountain known as Školska česma at the Niška Banja spa (Serbia), which is known for its high levels of Rn reaching several hundreds of $\mathrm{Bq} / \mathrm{L}$ (16-19). However, its natural ${ }^{226} \mathrm{Ra}$ content is negligible $(\sim 1 \mathrm{~Bq} / \mathrm{L})(5)$. All water was collected in a single $1.5 \mathrm{~L}$ glass bottle. Water samples were then pipetted into $20 \mathrm{~mL}$ glass vials (48 samples in total), and mixed with four scintillation cocktails (samples with each cocktail were prepared in 12 probes): one emulsifying to obtain a homogeneous mixture (one-phase samples) and three different water-immiscible cocktails to ensure separation of the aqueous and organic phase (two-phase samples). All samples were counted on a 1220 Quantulus $^{\mathrm{TM}}$ liquid scintillation counter (PerkinElmer, Shelton, CT, USA) to determine its baseline ${ }^{222} \mathrm{Rn}$ content at the sampling moment. Thirty-six of 48 samples were then spiked with standard ${ }^{226} \mathrm{Ra}$ solutions, as recommended for one- and two-phase samples (13), and recounted for several times over a two-month period.

\section{${ }^{222} \mathrm{Rn}$ measurement in water}

Sample preparation and counter calibration followed the method described by the US Environmental Protection Agency (US EPA) (13), which is appropriate for Rn determination in drinking water from groundwater and surface water sources in both one- and two-phase samples (20). The calibration factor CF (cpm/Bq) (detection efficiency of ${ }^{222} \mathrm{Rn}$ or ${ }^{226} \mathrm{Ra}$ ) was determined based on the calibration sample (Ra standard) count:

$$
\mathrm{CF}=\frac{\mathrm{S}-\mathrm{B}}{\mathrm{C} * \mathrm{~V}}
$$

where $\mathrm{S}$ (cpm) is the calibration standard count, $\mathrm{B}$ (cpm) background sample count, $\mathrm{C}(\mathrm{Bq} / \mathrm{L})$ is the concentration of ${ }^{226} \mathrm{Ra}$ standard solution, and $\mathrm{V}(\mathrm{L})$ is the volume of the calibration standard per analysed sample $(10 \mathrm{~mL}$ in our experiments).

The activity concentration of ${ }^{222} \mathrm{Rn}[A(\mathrm{~Bq} / \mathrm{L})]$ was calculated using the following formula:

$$
\mathrm{A}=\frac{\mathrm{G}-\mathrm{B}}{\mathrm{CF} * \mathrm{D} * \mathrm{~V}}
$$

where $\mathrm{G}(\mathrm{cpm})$ is the sample count and D the decay correction factor for ${ }^{222} \mathrm{Rn}$. This factor should be calculated for the time between sampling and midpoint of the counting $(t)$, as follows:

$$
\mathrm{D}=\exp \left(-\frac{\ln 2}{T_{1 / 2}} t\right)
$$

For Rn half-life $\left[T_{1 / 2}\left({ }^{222} \mathrm{Rn}\right)\right]$ we assumed 3.824 days.

Calibration involved preparation of calibration standards ( $10 \mathrm{~mL}$ of distilled water spiked with the known ${ }^{226} \mathrm{Ra}$ activity, mixed with $10 \mathrm{~mL}$ of scintillation cocktail, shaken, and set aside for 30 days to attain secular ${ }^{226} \mathrm{Ra} /{ }^{222} \mathrm{Rn}$ equilibrium) and background samples $(10 \mathrm{~mL}$ of distilled 
water mixed with $10 \mathrm{~mL}$ of scintillation cocktail) and was carried out as described earlier (21).

Two-phase samples must be shaken vigorously for a few minutes at least to ensure efficient $\mathrm{Rn}$ transfer from water to the organic phase (15). For recounts we repeated shaking and then waited for $2 \mathrm{~h}$ for the ${ }^{226} \mathrm{Ra} /{ }^{222} \mathrm{Rn}$ equilibrium to restore, as a number of studies have shown that repeated shaking of two-phase ${ }^{226} \mathrm{Ra}$ standard calibration samples before re-counting returns ${ }^{222} \mathrm{Rn}$ and ${ }^{222} \mathrm{Rn}$ progenies into the aqueous phase, which slightly reduces $\mathrm{Rn}$ detection efficiency (5-10\%) until the equilibrium is restored (22-23).

\section{Experimental setup and materials}

The reliability of Rn measurement in water depends greatly on the sampling technique, as inadequate procedure can lead to error. The drinking water we took from the fountain, for example, must not get in contact with air at any point during sampling or storage (24). We minimised Rn desorption by collecting water from a non-aerated spigot and filling a glass beaker (5 L) until it was overflowing, after which we submerged the $1.5 \mathrm{~L}$ glass bottle into the beaker upside-down and turned it up slowly to fill it with water and to eliminate any air bubbles (19). We then capped it, still submerged, with a teflon-lined cap.

The 1220 Quantulus ${ }^{\mathrm{TM}}$ LSC we used in our experiments is convenient for ultra-low-level measurements because of its own background reduction system that involves a passive shield and active guard detector based on anticoincidence counting (25). Samples with each cocktail were prepared in three probes and measured on LSC for 100 minutes in six cycles.

Rn measurements also depend on the correctly adjusted pulse shape analysis (PSA) parameter (26), whose values range between 1 and 256. Proper PSA settings make it possible to discriminate alpha from beta signals, that is, to measure both alpha and beta activities at the same time by directing alpha and beta signals in two separate spectra (25). The lowest limit of $\mathrm{Rn}$ detection on Quantulus can be achieved when optimal PSA value has been experimentally determined, PSA is activated (which greatly reduces alpha backgrounds), and Rn content is calculated from the alpha spectrum (14).

Spectral data were acquired and evaluated with the WinQ and EASYView software (PerkinElmer Life Sciences, Turku, Finland).

The experiments involved the use of a radioactive source, aqueous ${ }^{226} \mathrm{Ra}$ standard (Czech Metrology Institute, Brno, Czech Republic, ref. date 1/10/2013) with certified activity $A\left({ }^{226} \mathrm{Ra}\right)$ of $39.67 \mathrm{~Bq} / \mathrm{mL}$ and combined standard uncertainty of $0.5 \%$. All experiments were completed in the early $2018 .{ }^{226} \mathrm{Ra}$ progenies had been purified from the standard solution five years earlier to minimise interference from ${ }^{210} \mathrm{Po},{ }^{210} \mathrm{~Pb}$ and ${ }^{210} \mathrm{Bi}$ to max. $4 \%$ (27).
All samples were prepared in high-performance $20 \mathrm{~mL}$ glass vials (Perkin Elmer). For the emulsifying scintillation cocktail we used the Ultima Gold $\mathrm{AB}$ and for the three water-immiscible cocktails we used High Efficiency Mineral Oil Scintillator, Opti-Fluor O, and Ultima Gold F, all by Perkin Elmer. The Ultima Gold AB cocktail was reported to generate the alpha background spectrum, which suggests that this cocktail contains ${ }^{226} \mathrm{Ra}$ as an impurity (14). The Ultima Gold F cocktail uses di-isopropylnaphtalene (DIN) as solvent and needs more time for a clear phase separation than older (mineral oil or pseudocumene-based) kinds of cocktails but is more suitable for alpha-beta discrimination (6). The High Efficiency Mineral Oil Scintillator cocktail is a mixture of mineral oil (70-75\%) and pseudocumene (25-30\%) (15).

In the mixture of $10 \mathrm{~mL}$ of Opti-Fluor $\mathrm{O}$ and $10 \mathrm{~mL}$ of water, ${ }^{222} \mathrm{Rn}$ partition coefficients for water:cocktail:air are 1:48:2 (28). These coefficients reflect ${ }^{222} \mathrm{Rn}$ detection efficiency, which corresponds to the one third of the CF value (as the alpha spectrum contains ${ }^{222} \mathrm{Rn},{ }^{218} \mathrm{Po}$, and ${ }^{214} \mathrm{Po}$ ) (29). In our previous research (21) we investigated the dependence of CF on PSA settings (in the range from 30-90) and established that Opti-Fluor $\mathrm{O}$ and Mineral Oil had very similar CF in the 30-70 PSA range. Ultima Gold F had a slightly lower CF, while the emulsifying Ultima Gold AB cocktail had about $25 \%$ higher $\mathrm{CF}$ than its water-immiscible counterparts.

The experiments were divided in two parts. In the first part, vials with $10 \mathrm{~mL}$ of spa water and $10 \mathrm{~mL}$ of respective cocktail (48 samples in total) were kept in dark to avoid photoluminescence (this is a common LSC practice, but photoluminescence reactions occur in low-energy regions and would probably not have interfered with the Rn spectra). After $5 \mathrm{~h}$, all 48 samples were measured for mean baseline ${ }^{222} \mathrm{Rn}$ activity concentrations $\left(\mathrm{A}_{0}\right)$. Moreover, the activities for days $\sim 4$ (about one ${ }^{222} \mathrm{Rn}$ half-life), $\sim 9$ (two half-lives), and $\sim 31$ were also measured in 12 samples that were not spiked with Ra solution.

In the second part, the remaining 36 samples were spiked with $20 \mu \mathrm{L}, 100 \mu \mathrm{L}$, or $200 \mu \mathrm{L}$ of the ${ }^{226}$ Ra standard, which corresponds to ${ }^{226} \mathrm{Ra}$ activity concentrations of 79.34, 396.7 , or $793.4 \mathrm{~Bq} / \mathrm{L}$, respectively. Each sample type was prepared in triplicate. These were counted in six cycles of 100 min at different time points $(\sim 5, \sim 11, \sim 31$, and $\sim 64$ days after sample preparation), and the obtained counts were used to calculate Rn activity concentrations according to the US EPA method (13).

Based on ${ }^{222} \mathrm{Rn}$ decay, we also calculated its ${ }^{222} \mathrm{Rn}$ progeny activity concentrations (what we refer to as theoretical value) for the mean moment of counting $(\sim 5$, $\sim 11, \sim 31$, and $\sim 64$ days after sample preparation). Since $\mathrm{Rn} / \mathrm{Ra}$ equilibrium occurs after $\sim 30$ days, the measurements on days 31 and 64 in fact enabled determination of ${ }^{226} \mathrm{Ra}$ activity concentration. 


\section{Defining the PSA plateau}

The following subsection describes the optimisation of the alpha/beta discrimination circuit that can be applied for Perkin Elmer instruments. Conventional recommendation for optimum PSA setting involves counting of pure alpha and beta calibration samples (often ${ }^{214} \mathrm{Am}$ and ${ }^{90} \mathrm{Sr}$ ) and adjusting PSA where the spillover of alpha pulses into the beta spectrum and vice versa is equal and minimal (19). A PSA discriminator set in this manner is to some extent inadequate for ${ }^{222} \mathrm{Rn}$ determination by an LS counter, since PSA can be more precisely regulated with a ${ }^{222} \mathrm{Rn}$ standard, provided that the lowest beta spillover and alpha-to-beta count ratio match the theoretical value (15). The third possibility is the simplest but not as precise as the previous two. It requires recording the dependence of CF on PSA and selection of a working PSA discriminator within the range in which CF factor does not vary significantly $(7,29)$. This technique provides an optimal range for PSA selection, even though its value may lower the counting precision for up to a few percent, but the advantage is that this range does not vary significantly between different scintillation cocktails. We therefore made one experiment to obtain the optimal PSA range setting and used it for all scintillation cocktails as described below.

Figure 1 represents CF dependence on the chosen PSA value, which shifted in the experiments across its range from 1 to 256. The calibration factor CF (detection efficiency for ${ }^{222} \mathrm{Rn},{ }^{218} \mathrm{Po}$, and ${ }^{214} \mathrm{Po}$ radionuclides) was consistent for all ${ }^{226} \mathrm{Ra}$ concentration activities. Similar $\mathrm{CF}$ dependencies on PSA values have been reported by other authors $(6,7,29)$. It is clear that CF plateaus when PSA values are set between 40 and 90. Consequently, all measurements presented in this paper were performed with PSA set at 70 .

\section{RESULTS AND DISCUSSION}

\section{Comparison of LSC methods for ${ }^{222} \mathrm{Rn}$ measurement}

The first line of experiments established the accuracy of one- and two-phase LSC methods. Our findings seem to support earlier observations that Mineral Oil yields an overestimate and Ultima Gold $\mathrm{AB}$ an underestimate of ${ }^{222} \mathrm{Rn}$ activity concentrations (21), although the variability of our results excludes definitive conclusion on this point. Figure 2 shows measured ${ }^{222} \mathrm{Rn}$ activity concentrations at baseline $\left(A_{0}\right)$ and on days 4,9 , and 31 after sample preparation as well as theoretical ${ }^{222} \mathrm{Rn}$ concentrations calculated with radioactive decay formula. The consistency between these calculated theoretical predictions and ${ }^{222} \mathrm{Rn}$ activity concentrations measured on day 4,9 , and 31 for all scintillation cocktails confirms the reliability of the LSC methods to measure ${ }^{222} \mathrm{Rn}$ in water samples.

Considering the limits of detection for measuring ${ }^{222} \mathrm{Rn}$ and ${ }^{226} \mathrm{Ra}$ laid down by the Council Directive 2013/51/ EURATOM (30), the methods used should be able to detect activity concentrations as low as $10 \mathrm{~Bq} / \mathrm{L}$ and $40 \mathrm{mBq} / \mathrm{L}$, respectively (30). In our earlier report (21) minimal detectable activities (MDA) for ${ }^{222} \mathrm{Rn}$ over 300 minutes of counting were $38 \mathrm{mBq} / \mathrm{L}$ for Ultima Gold AB, $104 \mathrm{mBq} / \mathrm{L}$ for Ultima Gold F, $65 \mathrm{mBq} / \mathrm{L}$ for Mineral Oil, and $104 \mathrm{mBq} / \mathrm{L}$ for OptiFluor O, which shows that LSC methods are suitable for both direct ${ }^{222} \mathrm{Rn}$ and indirect ${ }^{226} \mathrm{Ra}$ detection, since the required MDA of $40 \mathrm{mBq} / \mathrm{L}$ for the latter is easily achievable if longer counting times are applied.

\section{${ }^{226} \mathrm{R}$ a effects on ${ }^{222} \mathrm{Rn}$ activity concentrations}

The average ${ }^{222} \mathrm{Rn}$ activity concentration in the baseline $\left(\mathrm{A}_{0}\right)$ spa water samples was $473( \pm 65) \mathrm{Bq} / \mathrm{L}$ (average of four

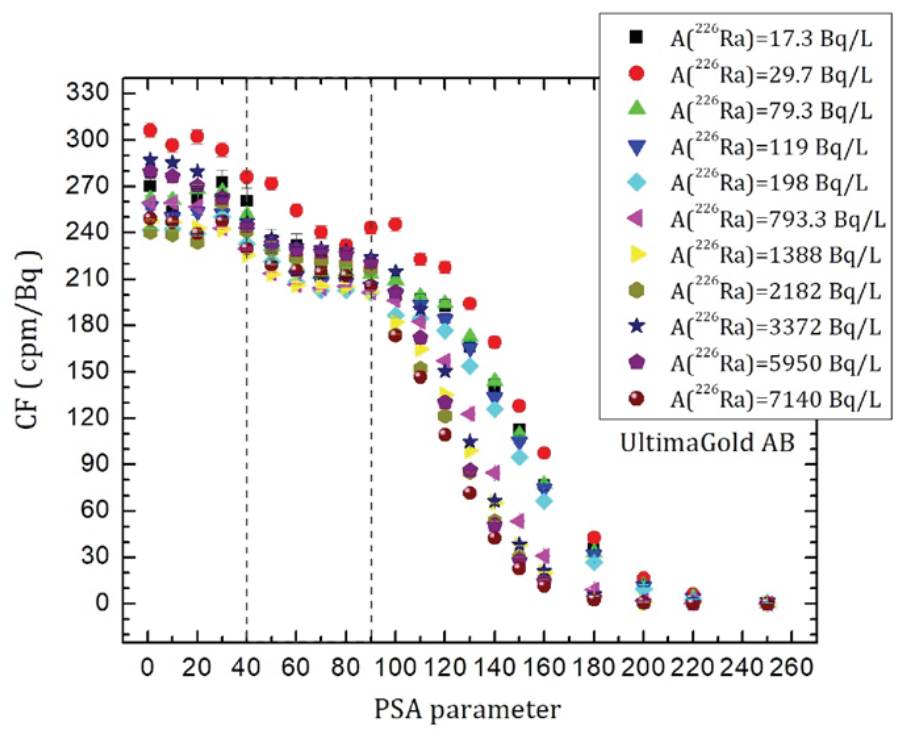

Figure 1 CF dependence on PSA value across its range (samples prepared with the Ultima Gold AB cocktail and spiked with different ${ }^{226} \mathrm{Ra}$ activities) 


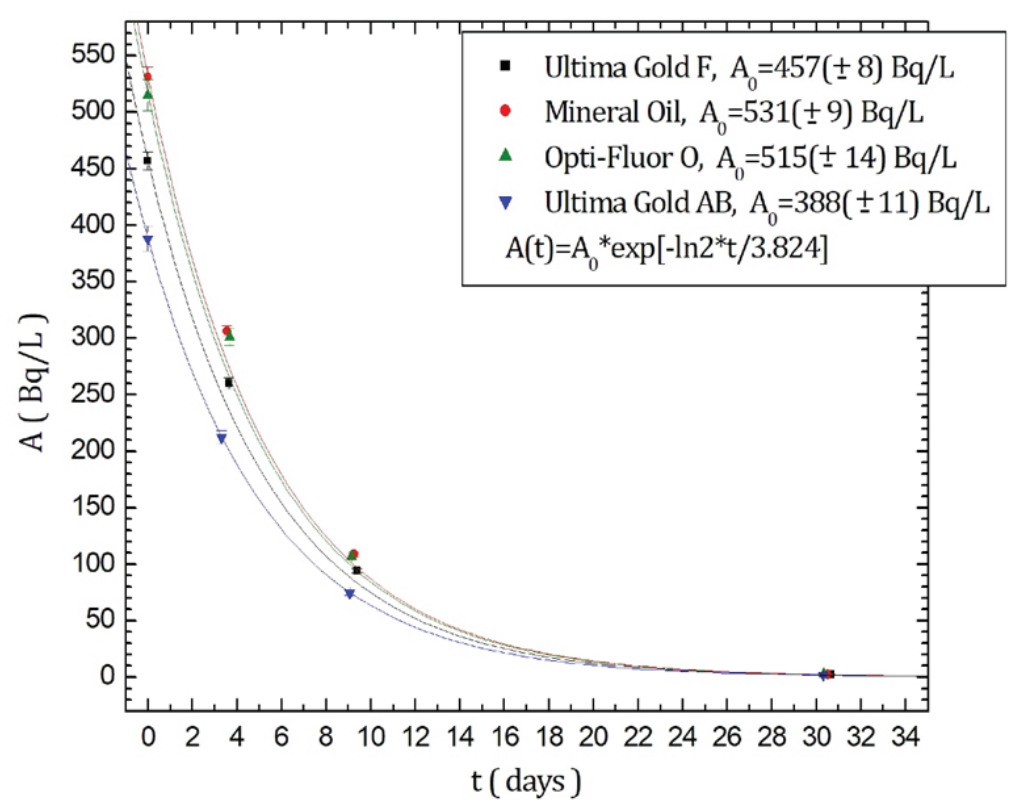

Figure 2 Accuracy of LSC methods for ${ }^{222} \mathrm{Rn}$ measurement in non-spiked Niška Banja spa water. $A_{0}$ - baseline activity measured $5 \mathrm{~h}$ after the samples were prepared and corrected for decay over this time

$A_{0}$ values in all four cocktails, Figure 2). Relying on the law of radioactive decay, we used four functions from Figure 2 to predict Rn activity over time. As mentioned before, the theoretical ${ }^{222} \mathrm{Rn}$ activity of the spa water was calculated based on decay at the moment of counting. Tables 1-4 show mean baseline, measured, and theoretical ${ }^{222} \mathrm{Rn}$ activity concentrations 5, 11,31, and 64 days after sampling.

The first two measurements were carried out while ${ }^{226} \mathrm{Ra}$ and ${ }^{222} \mathrm{Rn}$ were still not in the equilibrium, but on the third and the fourth measurement the equilibrium was there (after 30 days or eight ${ }^{222} \mathrm{Rn}$ half-lives). The latter measurements made it possible to evaluate the accuracy of LSC in one- and two-phase samples, since the original, naturally occurring ${ }^{222} \mathrm{Rn}$ from the spa water had completely decayed by that time and any leftover ${ }^{222} \mathrm{Rn}$ activity measured in these samples is therefore the result of the decay of spiked ${ }^{226} \mathrm{Ra}$ standard. The baseline theoretical ${ }^{222} \mathrm{Rn}$ activity represents measured activity corrected for sampling date and time, while all other values were derived from the law of radioactive decay. The activity concentration in the first measurement, made about five days after sampling, was corrected with respect to ${ }^{222} \mathrm{Rn}$ half-life in order to evaluate to which extent ${ }^{226} \mathrm{Ra}$ presence influenced ${ }^{222} \mathrm{Rn}$ results. These corrections were not carried out for other measurements, simply because it is not common laboratory practice to wait for more than two half-lives of a radionuclide of interest to count the samples, and it is clear that such corrected values would be enormous because of high spiked ${ }^{226} \mathrm{Ra}$ activities.

Tables 1-3 showing measurements in two-phase samples reveal no substantial differences between the cocktails. The results obtained for samples with the lowest spiked ${ }^{226} \mathrm{Ra}$ concentration $(79.34 \mathrm{~Bq} / \mathrm{L})$ were satisfactory for all three cocktails and for all four dates of counting, which indicates that $\mathrm{Ra}$ interferes with the $\mathrm{Rn}$ spectra because of the migration of its Rn progeny from the aqueous to the organic phase. With higher spiked ${ }^{226} \mathrm{Ra}$ concentrations (396.7 Bq/L and 793.4 Bq/L), however, it is clear that only a smaller fraction of ${ }^{226} \mathrm{Ra}$ presence (one fourth to one fifth) can be detected in samples with radioactive equilibrium, regardless on the measurement day. It is possible that some saturation effect occurs that limits Rn transfer to the organic phase. This is an interesting hypothesis that should be verified in a larger number of samples with different higher ${ }^{226} \mathrm{Ra}$ concentrations for better statistics.

The lowest activity concentrations were obtained with the Opti-Fluor O cocktail (Table 2), which points to the lowest interference from Ra decay. Namely, even with ${ }^{226} \mathrm{Ra}$ and ${ }^{222} \mathrm{Rn}$ in equilibrium, only about one fifth of ${ }^{222} \mathrm{Rn}$ from ${ }^{226} \mathrm{Ra}$ decay entered the organic phase.

This brings us to the main conclusion about two-phase samples, namely that Ra progeny ${ }^{222} \mathrm{Rn}$ entering the organic phase interferes with measuring the original $\mathrm{Rn}$ activity in a sample.

On the other hand, some of the obtained activities slightly exceed spiked ${ }^{226} \mathrm{Ra}$ content, even in the fourth measurement when all radon from the sample had decayed. The explanation lies in inadequately adjusted PSA(PSA=70 was probably not optimal value for the samples prepared with selected cocktails). If the activity concentration exceeds spiked ${ }^{226} \mathrm{Ra}$ concentration, there has been a spill of beta particles into the alpha spectrum during counting.

$\mathrm{Ra}$ interference is even more evident in one-phase LSC samples, especially before $\mathrm{Rn} / \mathrm{Ra}$ equilibrium was achieved. The obtained activities with the Ultima Gold AB cocktail were close to ${ }^{226} \mathrm{Ra}+{ }^{222} \mathrm{Rn}$ cumulative activities, while 
Table $1{ }^{222} \mathrm{Rn}$ activity in two-phase samples with Mineral Oil Scintillator

\begin{tabular}{|c|c|c|c|c|c|}
\hline \multicolumn{3}{|r|}{$\begin{array}{l}\text { Mineral Oil Scintillator } \\
\text { ROI: } 625-875 \mathrm{ch}\end{array}$} & \multirow{2}{*}{$\begin{array}{c}\begin{array}{c}\text { Spiked with } \\
A\left({ }^{226} \mathrm{Ra}\right)=79.34 \mathrm{~Bq} / \mathrm{L} \\
4.83\end{array}\end{array}$} & \multirow{2}{*}{$\begin{array}{c}\begin{array}{c}\text { Spiked with } \\
A\left({ }^{226} \mathrm{Ra}\right)= \\
\end{array} \\
4.96 .7 \mathrm{~Bq} / \mathrm{L}\end{array}$} & \multirow{2}{*}{$\begin{array}{c}\begin{array}{c}\text { Spiked with } \\
A(226 \mathrm{Ra})=793.4 \mathrm{~Bq} / \mathrm{L}\end{array} \\
5\end{array}$} \\
\hline \multirow{7}{*}{ 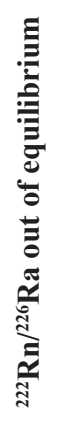 } & \multirow{4}{*}{ 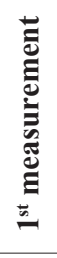 } & Days after sampling & & & \\
\hline & & Theoretical $A\left({ }^{222} \mathrm{Rn}\right)(\mathrm{Bq} / \mathrm{L})^{*}$ & $221( \pm 4)$ & $218( \pm 4)$ & $215( \pm 4)$ \\
\hline & & Measured $A\left({ }^{222} \mathrm{Rn}\right)(\mathrm{Bq} / \mathrm{L})$ & $286( \pm 4)$ & $414( \pm 6)$ & $441( \pm 6)$ \\
\hline & & $\begin{array}{l}A\left({ }^{222} \mathrm{Rn}\right)(\mathrm{Bq} / \mathrm{L}) \text { corrected on the } \\
\text { sampling day** }\end{array}$ & $688( \pm 9)$ & $1010( \pm 13)$ & $1092( \pm 14)$ \\
\hline & \multirow{3}{*}{ 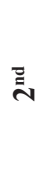 } & Days after sampling & 11.08 & 11.17 & 11.25 \\
\hline & & Theoretical $A\left({ }^{222} \mathrm{Rn}\right)(\mathrm{Bq} / \mathrm{L})$ & $71.2( \pm 1.2)$ & $70.2( \pm 1.2)$ & $69.1( \pm 1.2)$ \\
\hline & & Measured $A\left({ }^{222} \mathrm{Rn}\right)(\mathrm{Bq} / \mathrm{L})$ & $154.2( \pm 2.3)$ & $204( \pm 3)$ & $243( \pm 3)$ \\
\hline \multirow{6}{*}{ 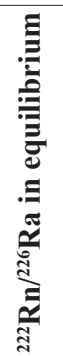 } & \multirow{3}{*}{$\bar{m}$} & Days after sampling & 31.3 & 31.4 & 31.5 \\
\hline & & Theoretical $A\left({ }^{222} \mathrm{Rn}\right)(\mathrm{Bq} / \mathrm{L})$ & $1.82( \pm 0.03)$ & $1.79( \pm 0.03)$ & $1.77( \pm 0.03)$ \\
\hline & & Measured $A\left({ }^{222} \mathrm{Rn}\right)(\mathrm{Bq} / \mathrm{L})$ & $93.0( \pm 1.6)$ & $85.5( \pm 1.5)$ & $161.7( \pm 2.4)$ \\
\hline & \multirow{3}{*}{$\bar{E}$} & Days after sampling & 64.1 & 64.2 & 64.2 \\
\hline & & Theoretical $A\left({ }^{222} \mathrm{Rn}\right)(\mathrm{Bq} / \mathrm{L})$ & $0.00479( \pm 0.00008)$ & $0.00472( \pm 0.00008)$ & $0.00465( \pm 0.00008)$ \\
\hline & & Measured $A\left({ }^{222} \mathrm{Rn}\right)(\mathrm{Bq} / \mathrm{L})$ & $88.8( \pm 1.5)$ & $74.9( \pm 1.4)$ & $153.0( \pm 2.3)$ \\
\hline
\end{tabular}

${ }^{*}$ Theoretical $A\left({ }^{222} \mathrm{Rn}\right)$ represents the measured activity corrected for the sampling time. ${ }^{* *}$ Decay corrections five days after sampling lead to extremely high $A\left({ }^{222} \mathrm{Rn}\right)$ values (compared to theoretical $A$ and spiked ${ }^{226} \mathrm{Ra}$ activity), which is why these corrected values were not calculated in further measurements

Table $2{ }^{222} \mathrm{Rn}$ activity in two-phase samples with Opti-Fluor O

\begin{tabular}{|c|c|c|c|c|c|}
\hline \multicolumn{3}{|c|}{$\begin{array}{l}\text { Opti-Fluor O } \\
\text { ROI: } 650-910 \mathrm{ch}\end{array}$} & $\begin{array}{c}\text { Spiked with } \\
A\left({ }^{226} \mathrm{Ra}\right)=79.34 \mathrm{~Bq} / \mathrm{L}\end{array}$ & $\begin{array}{c}\text { Spiked with } \\
A\left({ }^{226} \mathrm{Ra}\right)=396.7 \mathrm{~Bq} / \mathrm{L}\end{array}$ & $\begin{array}{c}\text { Spiked with } \\
A\left({ }^{226} \mathrm{Ra}\right)=793.4 \mathrm{~Bq} / \mathrm{L}\end{array}$ \\
\hline \multirow{7}{*}{ 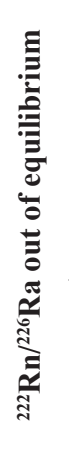 } & \multirow{4}{*}{ 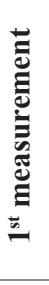 } & Days after sampling & 5.15 & 5.19 & 5.23 \\
\hline & & $\begin{array}{l}\text { Theoretical } A\left({ }^{222} \mathrm{Rn}\right) \\
(\mathrm{Bq} / \mathrm{L}) *\end{array}$ & $203( \pm 6)$ & $201( \pm 5)$ & $200( \pm 5)$ \\
\hline & & Measured $A\left({ }^{222} \mathrm{Rn}\right)(\mathrm{Bq} / \mathrm{L})$ & $260( \pm 7)$ & $366( \pm 9)$ & $394( \pm 10)$ \\
\hline & & $\begin{array}{l}A\left({ }^{(222} \mathrm{Rn}\right)(\mathrm{Bq} / \mathrm{L}) \text { corrected } \\
\text { on the sampling day** }\end{array}$ & $661( \pm 17)$ & $937( \pm 24)$ & $1016( \pm 26)$ \\
\hline & \multirow{3}{*}{ స̆丶 } & Days after sampling & 11.40 & 11.44 & 11.48 \\
\hline & & Theoretical $A\left({ }^{222} \mathrm{Rn}\right)(\mathrm{Bq} / \mathrm{L})$ & $65.3( \pm 1.8)$ & $64.8( \pm 1.8)$ & $64.3( \pm 1.7)$ \\
\hline & & Measured $A\left({ }^{222} \mathrm{Rn}\right)(\mathrm{Bq} / \mathrm{L})$ & $140( \pm 4)$ & $171( \pm 5)$ & $206( \pm 5)$ \\
\hline \multirow{6}{*}{ 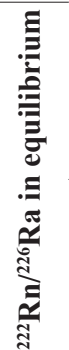 } & \multirow{3}{*}{ 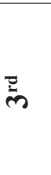 } & Days after sampling & 31.6 & 31.7 & 31.7 \\
\hline & & Theoretical $A\left({ }^{222} \mathrm{Rn}\right)(\mathrm{Bq} / \mathrm{L})$ & $1.67( \pm 0.05)$ & $1.66( \pm 0.05)$ & $1.64( \pm 0.04)$ \\
\hline & & Measured $A\left({ }^{222} \mathrm{Rn}\right)(\mathrm{Bq} / \mathrm{L})$ & $85.6( \pm 2.4)$ & $68.0( \pm 2.0)$ & $127( \pm 3)$ \\
\hline & \multirow{3}{*}{ 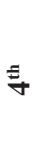 } & Days after sampling & 64.4 & 64.4 & 64.5 \\
\hline & & Theoretical $A\left({ }^{222} \mathrm{Rn}\right)(\mathrm{Bq} / \mathrm{L})$ & $0.00439( \pm 0.00012)$ & $0.00436( \pm 0.00012)$ & $0.00432( \pm 0.00012)$ \\
\hline & & Measured $A\left({ }^{222} \mathrm{Rn}\right)(\mathrm{Bq} / \mathrm{L})$ & $66.3( \pm 1.9)$ & $67.9( \pm 2.0)$ & $130( \pm 4)$ \\
\hline
\end{tabular}

${ }^{*}$ Theoretical $A\left({ }^{222} \mathrm{Rn}\right)$ represents the measured activity corrected for the sampling time. ${ }^{* *}$ Decay corrections five days after sampling lead to extremely high $A\left({ }^{222} \mathrm{Rn}\right)$ values (compared to theoretical $A$ and spiked ${ }^{226} \mathrm{Ra}$ activity), which is why these corrected values were not calculated in further measurements 
Table $3^{222} \mathrm{Rn}$ activity in two-phase samples with Ultima Gold F

\begin{tabular}{|c|c|c|c|c|c|}
\hline \multicolumn{3}{|c|}{$\begin{array}{l}\text { Ultima Gold F } \\
\text { ROI: } 730-970 \mathrm{ch}\end{array}$} & $\begin{array}{c}\text { Spiked with } \\
A\left({ }^{226} \mathrm{Ra}\right)=79.34 \mathrm{~Bq} / \mathrm{L}\end{array}$ & $\begin{array}{c}\text { Spiked with } \\
A\left({ }^{226} \mathrm{Ra}\right)=396.7 \mathrm{~Bq} / \mathrm{L}\end{array}$ & $\begin{array}{c}\text { Spiked with } \\
A\left({ }^{226} \mathrm{Ra}\right)=793.4 \mathrm{~Bq} / \mathrm{L}\end{array}$ \\
\hline \multirow{7}{*}{ 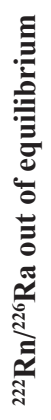 } & \multirow{4}{*}{ 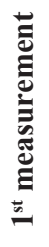 } & Days after sampling & 5.04 & 5.08 & 5.13 \\
\hline & & Theoretical $A\left({ }^{222} \mathrm{Rn}\right)(\mathrm{Bq} / \mathrm{L}) *$ & $183( \pm 3)$ & $182( \pm 3)$ & $180( \pm 3)$ \\
\hline & & Measured $A\left({ }^{222} \mathrm{Rn}\right)(\mathrm{Bq} / \mathrm{L})$ & $277( \pm 5)$ & $387( \pm 7)$ & $415( \pm 7)$ \\
\hline & & $\begin{array}{l}A\left({ }^{222} \mathrm{Rn}\right)(\mathrm{Bq} / \mathrm{L}) \text { corrected on the } \\
\text { sampling day** }\end{array}$ & $691( \pm 12)$ & $973( \pm 16)$ & $1051( \pm 18)$ \\
\hline & \multirow{3}{*}{ స్ } & Days after sampling & 11.29 & 11.33 & 11.38 \\
\hline & & Theoretical $A\left({ }^{222} \mathrm{Rn}\right)(\mathrm{Bq} / \mathrm{L})$ & $59.0( \pm 1.0)$ & $58.6( \pm 1.0)$ & $58.1( \pm 1.0)$ \\
\hline & & Measured $A\left({ }^{222} \mathrm{Rn}\right)(\mathrm{Bq} / \mathrm{L})$ & $154.2( \pm 2.8)$ & $203( \pm 4)$ & $210( \pm 4)$ \\
\hline \multirow{6}{*}{ 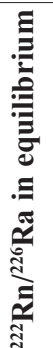 } & \multirow{3}{*}{$\bar{m}$} & Days after sampling & 31.5 & 31.5 & 31.6 \\
\hline & & Theoretical $A\left({ }^{222} \mathrm{Rn}\right)(\mathrm{Bq} / \mathrm{L})$ & $1.514( \pm 0.027)$ & $1.503( \pm 0.026)$ & $1.492( \pm 0.026)$ \\
\hline & & Measured $A\left({ }^{222} \mathrm{Rn}\right)(\mathrm{Bq} / \mathrm{L})$ & $89.9( \pm 1.8)$ & $99.4( \pm 1.9)$ & $113.6( \pm 2.2)$ \\
\hline & \multirow{3}{*}{ 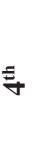 } & Days after sampling & 64.3 & 64.3 & 64.4 \\
\hline & & Theoretical $A\left({ }^{222} \mathrm{Rn}\right)(\mathrm{Bq} / \mathrm{L})$ & $0.00397( \pm 0.00007)$ & $0.00394( \pm 0.00007)$ & $0.00391( \pm 0.00007)$ \\
\hline & & Measured $A\left({ }^{222} \mathrm{Rn}\right)(\mathrm{Bq} / \mathrm{L})$ & $87.1( \pm 1.7)$ & $91.7( \pm 1.8)$ & $100.4( \pm 1.9)$ \\
\hline
\end{tabular}

${ }^{*}$ Theoretical $A\left({ }^{222} \mathrm{Rn}\right)$ represents the measured activity corrected for the sampling time. ${ }^{* *}$ Decay corrections five days after sampling lead to extremely high $A\left({ }^{222} \mathrm{Rn}\right)$ values (compared to theoretical $A$ and spiked ${ }^{226} \mathrm{Ra}$ activity), which is why these corrected values were not calculated in further measurements

Table $4{ }^{222} \mathrm{Rn}$ activity in one-phase samples with Ultima Gold AB

\begin{tabular}{|c|c|c|c|c|c|}
\hline \multicolumn{3}{|c|}{$\begin{array}{l}\text { Ultima Gold AB } \\
\text { ROI: } 430-790 \mathrm{ch}\end{array}$} & $\begin{array}{c}\text { Spiked with } \\
A\left({ }^{226} \mathrm{Ra}\right)=79.34 \mathrm{~Bq} / \mathrm{L}\end{array}$ & $\begin{array}{c}\text { Spiked with } \\
A\left({ }^{226} \mathrm{Ra}\right)=396.7 \mathrm{~Bq} / \mathrm{L}\end{array}$ & $\begin{array}{c}\text { Spiked with } \\
A\left({ }^{226} \mathrm{Ra}\right)=793.4 \mathrm{~Bq} / \mathrm{L}\end{array}$ \\
\hline \multirow{7}{*}{ 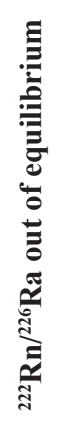 } & \multirow{4}{*}{ 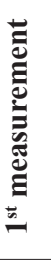 } & Days after sampling & 4.60 & 4.69 & 4.77 \\
\hline & & Theoretical $A\left({ }^{222} \mathrm{Rn}\right)(\mathrm{Bq} / \mathrm{L})^{*}$ & $168( \pm 5)$ & $166( \pm 5)$ & $163( \pm 5)$ \\
\hline & & Measured $A\left({ }^{222} \mathrm{Rn}\right)(\mathrm{Bq} / \mathrm{L})$ & $216( \pm 5)$ & $441( \pm 11)$ & $723( \pm 18)$ \\
\hline & & $\begin{array}{l}A\left({ }^{222} \mathrm{Rn}\right)(\mathrm{Bq} / \mathrm{L}) \text { corrected on the } \\
\text { sampling day** }\end{array}$ & $498( \pm 13)$ & $1031( \pm 26)$ & $1718( \pm 42)$ \\
\hline & \multirow{3}{*}{ స̆ } & Days after sampling & 10.85 & 10.94 & 11.00 \\
\hline & & Theoretical $A\left({ }^{222} \mathrm{Rn}\right)(\mathrm{Bq} / \mathrm{L})$ & $54.2( \pm 1.5)$ & $53.4( \pm 1.5)$ & $52.6( \pm 1.5)$ \\
\hline & & Measured $A\left({ }^{222} \mathrm{Rn}\right)(\mathrm{Bq} / \mathrm{L})$ & $130( \pm 3)$ & $442( \pm 11)$ & $838( \pm 21)$ \\
\hline \multirow{6}{*}{ 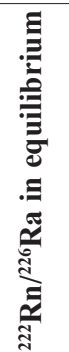 } & \multirow{3}{*}{$\bar{m}$} & Days after sampling & 31.1 & 31.2 & 31.2 \\
\hline & & Theoretical $A\left({ }^{222} \mathrm{Rn}\right)(\mathrm{Bq} / \mathrm{L})$ & $1.39( \pm 0.04)$ & $1.37( \pm 0.04)$ & $1.35( \pm 0.04)$ \\
\hline & & Measured $A\left({ }^{222} \mathrm{Rn}\right)(\mathrm{Bq} / \mathrm{L})$ & $88.16( \pm 0.23)$ & $430( \pm 11)$ & $863( \pm 21)$ \\
\hline & \multirow{3}{*}{ 吾 } & Days after sampling & 63.9 & 63.9 & 64.0 \\
\hline & & Theoretical $A\left({ }^{222} \mathrm{Rn}\right)(\mathrm{Bq} / \mathrm{L})$ & $0.00365( \pm 0.00010)$ & $0.00359( \pm 0.00010)$ & $0.00354( \pm 0.00010)$ \\
\hline & & Measured $A\left({ }^{222} \mathrm{Rn}\right)(\mathrm{Bq} / \mathrm{L})$ & $87.6( \pm 2.3)$ & $425( \pm 11)$ & $842( \pm 21)$ \\
\hline
\end{tabular}

${ }^{*}$ Theoretical $A\left({ }^{222} \mathrm{Rn}\right)$ represents the measured activity corrected for the sampling time. ${ }^{* *}$ Decay corrections five days after sampling lead to extremely high $A\left({ }^{222} \mathrm{Rn}\right)$ values (compared to theoretical $A$ and spiked ${ }^{226} \mathrm{Ra}$ activity), which is why these corrected values were not calculated in further measurements 


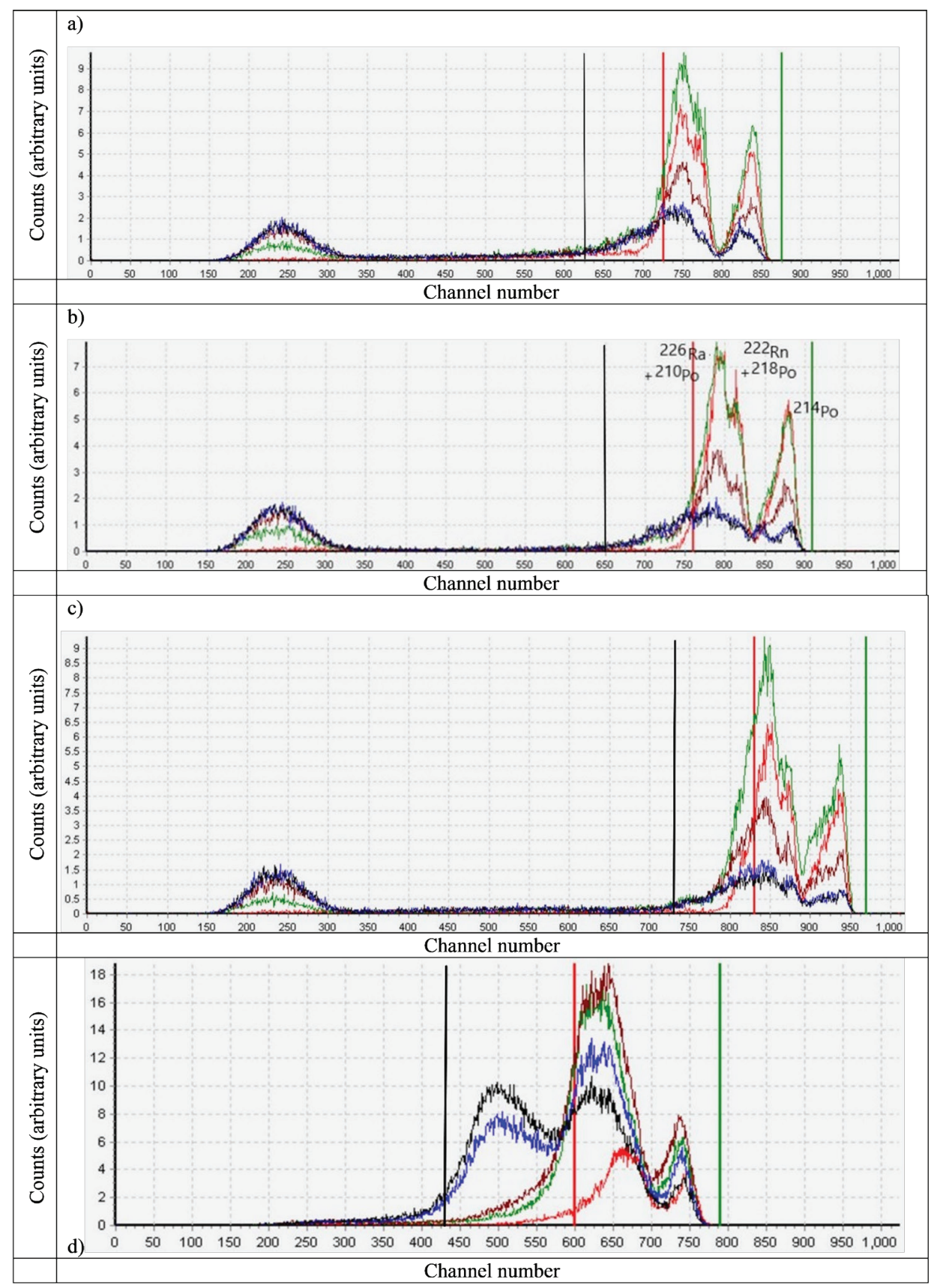

Figure 3 Generated spectra with the four scintillation cocktails in non-spiked spa water sample at baseline (red) and samples spiked with the lowest ${ }^{226} \mathrm{Ra}$ activity concentration $(79 \mathrm{~Bq} / \mathrm{L}$ ) on days 5 (green), 11 (brown), 31 (blue), and 64 (black). a) Mineral Oil, original ROI: 725-875, expanded ROI: 625-875 ch; b) Opti-Fluor O, original ROI: 760-910 ch, expanded ROI: 650-910 ch; c) Ultima Gold F, original ROI: 830-970 ch, expanded ROI: 730-970 ch; d) Ultima Gold AB, original ROI: 600-790 ch, expanded ROI: 430-790 ch; ROI - region of interest

two-phase samples (regardless of the cocktail) gave much lower activity concentrations. Obviously, the two-phase method provides more accurate ${ }^{222} \mathrm{Rn}$ measurements in the presence of high ${ }^{226} \mathrm{Ra}$ content in samples if counting is performed in the first few days after the sampling, that is, before radioactive equilibrium is achieved.

The one-phase method offers a more reliable indirect assessment of ${ }^{226} \mathrm{Ra}$ concentration later, when radioactive equilibrium is achieved, while the two-phase LSC had satisfying accuracy only with the lowest spiked ${ }^{226} \mathrm{Ra}$ concentration. At higher spiked activity concentrations all three water-immiscible cocktails showed some kind of "saturation" limit that allows only so much of Ra in the form of its ${ }^{222} \mathrm{Rn}$ progeny to enter the organic phase from water when the ${ }^{222} \mathrm{Rn} /{ }^{226} \mathrm{Ra}$ equilibrium is reached.

What this research suggests, however, is that LS counts in one-phase samples can be precise if the PSA level is set correctly. An even more precise, yet indirect, measurement of native ${ }^{222} \mathrm{Rn}$ (i.e. not the Ra progeny) would involve purging it from a water sample with nitrogen or argon or 
by boiling it to evaporate. The obtained "background" sample would then contain only the remaining radionuclides and serve to measure ${ }^{226} \mathrm{Ra}$ activity concentration (if the presence of other radionuclides can be excluded by some other chemical pre-treatments), which can be deducted from the baseline measurement in the one-phase sample. However, this would take more time and resources.

Speaking of ${ }^{226} \mathrm{Ra}$ activities, we would also like to address the issue of extremely high findings compared to the ones in the non-spiked samples. The purpose of our experiments was to investigate the effect Ra on the accuracy of native ${ }^{222} \mathrm{Rn}$ measurements, which, we assumed, would be the most obvious if spiking involved high ${ }^{226} \mathrm{Ra}$ activities, and we were right about that, but interference rendered these measurements completely useless (which is why we did not use them in analysis). Further research would, therefore, do better by exploring the demonstrated phenomena in the presence of much lower ${ }^{226} \mathrm{Ra}$ activities than the ones we used for spiking.

\section{Sample stability}

Throughout the measurements we noticed that the spectra of the spiked samples broadened over time (expanding partly into the lower-channel region). We therefore had to recalibrate and recalculate all results in Tables 1-4 for a wider ROI (given in each table), for which we repeated calibration procedure as described elsewhere (21). Changes in the spectral shape for all four cocktails are presented in Figure 3. The initial ROI expanded for approximately 100 channels towards the lower energy region. Figure $3 \mathrm{~b}$ shows the peaks of certain radionuclides relevant for all other spectra.

One of the reasons why the spectral shapes evolved diversely (still following a similar pattern) between the water-immiscible cocktails was unequal transfer of ${ }^{210} \mathrm{Po}$ from the ${ }^{226} \mathrm{Ra}$ standard solution to different organic cocktails, which appears as the ${ }^{222} \mathrm{Rn}+{ }^{218} \mathrm{Po}$ peak broadening to the left $(15,27)$. The greatest affinity of ${ }^{210} \mathrm{Po}$ for the organic phase was observed in the Mineral Oil Scintillator (15). This broadening to the left also indicates that alpha energies were absorbed in water at the interface (15). Smaller discrepancies between the three waterimmiscible cocktails can also be the result of different ${ }^{210} \mathrm{~Pb}$ and ${ }^{210} \mathrm{Bi}$ transfer to the organic phase during shaking (15). It is also possible that shaking does not achieve $100 \%$ water-to-cocktail transfer of ${ }^{222} \mathrm{Rn}$ progeny of ${ }^{226} \mathrm{Ra}$ from the standard solution in all cocktails over time, and that short-lived progenies of ${ }^{222} \mathrm{Rn},{ }^{214} \mathrm{~Pb}$ and ${ }^{214} \mathrm{Bi}$, migrate differently from various cocktails to the water phase (these effects could lower detection efficiency by up to several percent) (15).

In similar experiments, spectral evolution of ${ }^{226}$ Ra over five months was a result of the presence of several radionuclides in disequilibrium between the two phases, whose spectra overlapped. However, the counts varied within the $5 \%$ margin (31). The instability of the two-phase samples over longer periods of time is owed to radiological and chemical equilibration between the liquid (water), cocktail (organic), and air (gaseous) phases, which are affected by vial shaking, temperature, type of cocktail and vial, and by the presence of a carrier that reduces accumulation of long-lived progeny on the glass walls of the vial (22). The ${ }^{226} \mathrm{Ra}$ standard solution used in this study contains $\mathrm{Ba}$ as a carrier (the solution is composed of $1 \mathrm{~g} / \mathrm{L}$ of $\mathrm{BaCl}_{2}+10 \mathrm{~g} / \mathrm{L}$ of $\mathrm{HCl}$ ), and it was determined earlier that ${ }^{210} \mathrm{~Pb}$ can migrate to the water phase if the glass and the cocktail phase are saturated with the carrier (15).

Glass vial fluorescence generates low-energy peaks in the alpha spectrum in channels $1-300$ (32), but it is also possible that some of the beta particles spilled over to the alpha spectrum (Cherenkov effect of beta progenies, dominantly ${ }^{210} \mathrm{Bi}$ ) if PSA was not precisely adjusted.

During all LSC measurements, we monitored the quench parameter, since quenching can greatly impact detection efficiency and spectral shape. The vials were tightly sealed all the time to exclude oxygen as potential quencher. We observed no spectral shift owed to quenching in the ${ }^{226} \mathrm{Ra}$ standard solution investigated in an earlier research (26) (Figure 3), nor did the spectral quench parameter of the external standard [SPQ(E)] alter significantly, which is a reliable indicator that quenching did not occur in our experiments.

However, sample stability and the overall spectral evolution presented in Figure 3 were certainly affected by the chemical composition of the spa water sample, which depends on local geology.

The fact that spectral evolution was unique for each cocktail points out that calibration can be challenging if measurements span across longer periods of time and calls for careful consideration.

\section{CONCLUSIONS}

The experiments presented in this paper are innovative, as their results not only confirm the well-known theory but also provide some new insights into the familiar LSC practice.

LSC in one-phase samples gives more precise and reliable ${ }^{222} \mathrm{Rn}$ concentrations than in two-phase samples in general, but it does not discriminate between Rn originally present in the sample and $\mathrm{Rn}$ produced by ${ }^{226} \mathrm{Ra}$ decay ( $\mathrm{Ra}$ interference depends on the achieved degree of $\mathrm{Ra} / \mathrm{Rn}$ equilibrium). The two-phase LSC yields more accurate measurements of native ${ }^{222} \mathrm{Rn}$ activity concentrations than one-phase LSC, as ${ }^{226} \mathrm{Ra}$ contribution through its ${ }^{222} \mathrm{Rn}$ progeny is much smaller. However, the one-phase method is better for indirect ${ }^{226} \mathrm{Ra}$ measurement (30 days after sampling) because the organic phase of water-immiscible cocktails can be saturated and not receive all ${ }^{222} \mathrm{Rn}$ progeny of $\mathrm{Ra}$, which calls for further investigation. In addition, 
spectral evolution of ${ }^{226} \mathrm{Ra}$ samples and the instability of the two-phase samples makes calibration rather challenging if measurements should span over longer time periods.

What we have also learned from our experiments is that samples with naturally high ${ }^{222} \mathrm{Rn}$ content should not be spiked with ${ }^{226} \mathrm{Ra}$ activities higher than the ones found in native samples. Further research would require much lower ${ }^{226} \mathrm{Ra}$ activities for spiking to provide more practical answers to questions arising from the demonstrated phenomena.

\section{Acknowledgements}

We wish to acknowledge the financial support of the Provincial Secretariat for Higher Education and Scientific Research, Republic of Serbia (projects No. 142-451-2505, "Radioactivity in drinking water and cancer incidence in Vojvodina" and No. 142-451-2373/2021-01, "Development of environmentally safe method based on ionic liquids for the investigation of radiological content of drinking waters in Vojvodina") and of the Ministry of Education, Science and Technological Development of the Republic of Serbia (grants No. 451-03-68/2020-14/200125 and 01-209/21-1 "Innovative scientific and artistic research from the domain of the activity of Faculty of Technical Sciences").

\section{REFERENCES}

1. Bean JA, Isacson P, Hausler WJJr, Kohler J. Drinking water and cancer incidence in Iowa. 1. Trends and incidence by source of drinking water and size of municipality. Am J Epidemiol 1982;116:912-23. doi: 10.1093/oxfordjournals. aje.a113493

2. Petersen NJ, Samuels LD, Lucas HF, Abrahamset SP. An epidemiologic approach to low-level radium 226 exposure. Public Health Rep 1966;81:805-14. doi: 10.2307/4592839

3. Lyman GH, Lyman CG, Johnson W. Association of leukemia with radium groundwater contamination. JAMA 1985;254:621-6. doi: 10.1001/jama.1985.03360050059026

4. National Research Council (US) Committee on Risk Assessment of Exposure to Radon in Drinking Water. Risk Assessment of Radon in Drinking Water. Washington (DC): National Academy Press; 1999.

5. Todorović N, Nikolov J, Petrović Pantić T, Kovačević J, Stojković I, Krmar M. Radon in water - hydrogeology and health implication. In: Stacks AM, editor. Radon, geology, environmental impact, and toxicity concerns. Nova Science Publishers; 2015. p. 163-88.

6. Forte M, Abbate G, Badalamenti P, Costantino S, Lunesu D, Rusconi R. Validation of a method for measuring ${ }^{226} \mathrm{Ra}$ in drinking waters by LSC. Appl Radiat Isot 2015;103:143-50. doi: 10.1016/j.apradiso.2015.05.022

7. Bhade SPD, Reddy PJ, Anilkumar S, Singhal RK, Rao DD. Calibration and optimization of alpha-beta separation procedures for determination of radium/radon in single- and two-phase liquid scintillation systems. J Radioanal Nucl Chem 2018;315:13-20. doi: 10.1007/s10967-017-5643-x

8. Alomari AH, Saleh MA, Hashim S, Alsayaheen A, Abdeldin I. Activity concentrations of ${ }^{226} \mathrm{Ra},{ }^{228} \mathrm{Ra},{ }^{222} \mathrm{Rn}$ and their health impact in the groundwater of Jordan. J Radioanal Nucl Chem 2019;322:305-18. doi: 10.1007/s10967-019-06686-4

9. Hou X. Liquid scintillation counting for determination of radionuclides in environmental and nuclear application. J Radioanal Nucl Chem 2018;318:1597-628. doi: 10.1007/ s10967-018-6258-6

10. Al-Hamarneh IF, Almasoud FI. A comparative study of different radiometric methodologies for the determination of ${ }^{226} \mathrm{Ra}$ in water. Nucl Eng Technol 2018;50:159-64. doi: 10.1016/j.net.2017.10.009

11. Lopes I, Vesterbacka P, Kelleher K. Comparison of radon (Rn-222) concentration in Portugal and Finland underground waters. J Radioanal Nucl Chem 2017;311:1867-73. doi: 10.1007/s10967-017-5166-5

12. Vinson DS, Vengosh A, Hirschfeld D, Dwyer GS. Relationships between radium and radon occurrence and hydrochemistry in fresh groundwater from fractured crystalline rocks, North Carolina (USA). Chem Geol 2009;260:159-71. doi: 10.1016/j.chemgeo.2008.10.022

13. Hahn PB, Pia SH. Method 913.0: Determination of Radon in Drinking Water by Liquid Scintillation Counting (Draft). Las Vegas (Nevada): Environmental Monitoring Systems Laboratory, U.S. Environmental Protection Agency; 1991.

14. Salonen L, Hukkanen H. Advantages of low-background liquid scintillation alpha-spectrometry and pulse shape analysis in measuring ${ }^{222} \mathrm{Rn}$, uranium and ${ }^{226} \mathrm{Ra}$ in groundwater samples. J Radioanal Nucl Chem 1997;226:67-74. doi: 10.1007/BF02063626

15. Salonen L. Comparison of two direct LS methods for measuring ${ }^{222} \mathrm{Rn}$ in drinking water using $\alpha / \beta$ liquid scintillation spectrometry. Appl Radiat Isot 2010;68:1970-9. doi: 10.1016/j.apradiso.2010.03.003

16. Manić G, Petrović S, Manić V, Popović D, Todorović D. Radon concentrations in a spa in Serbia. Environ Int 2006;32:533-7. doi: 10.1016/j.envint.2005.12.002

17. Žunić ZS, Kobal I, Vaupotič J, Kozak K, Mazur J, Birovljev A, Janik M, Čeliković I, Ujić P, Demajo A, Krstić G, Jakupi B, Quarto M, Bochicchio F. High natural radiation exposure in radon spa areas: a detailed field investigation in Niška Banja (Balkan region). J Environ Radioactiv 2006;89:24960. doi: 10.1016/j.jenvrad.2006.05.010

18. Nikolov J, Todorović N, Petrović Pantić T, Forkapić S, Mrdja D, Bikit I, Krmar M, Vesković M. Exposure to radon in the radon spa Niška Banja, Serbia. Radiat Meas 2012;47:443-50. doi: 10.1016/j.radmeas.2012.04.006

19. Stojković I, Tenjović B, Nikolov J, Vesković M, Mrđa D, Todorović N. Improvement of measuring methods and instrumentation concerning ${ }^{222} \mathrm{Rn}$ determination in drinking waters - RAD7 and LSC technique comparison. Appl Radiat Isot 2015;98:117-24. doi: 10.1016/j.apradiso.2015.01.028

20. Todorović N, Jakonić I, Nikolov J, Hansman J, Vesković M. Establishment of a method for ${ }^{222} \mathrm{Rn}$ determination by lowlevel liquid scintillation counter. Radiat Prot Dosim 2014;162:110-4. doi: 10.1093/rpd/ncu240

21. Nikolov J, Stojković I, Todorović N, Tenjović B, Vuković S, Knežević J. Evaluation of different LSC methods for ${ }^{222} \mathrm{Rn}$ determination in water. Appl Radiat Isot 2018;142:56-63. doi: 10.1016/j.apradiso.2018.09.013

22. Vitz E. Toward a standard method for determining waterborne radon. Health Phys 1991;60:817-29. doi: 10.1097/00004032199106000-00007 
23. Kitto ME. Characteristics of liquid scintillation analysis of radon in water. J Radioanal Nucl Chem 1994;185:91-9. doi: 10.1007/BF02042955

24. Todorović N, Nikolov J, Forkapić S, Bikit I, Mrđa D, Krmar M, Vesković M. Public exposure to radon in drinking water in Serbia. Appl Radiat Isot 2012;70:543-9. doi: 10.1016/j. apradiso.2011.11.045

25. PerkinElmer Life Sciences. Instrument manual- Quantulus ${ }^{\mathrm{TM}}$ 1220 ultra low level liquid scintillation spectrometer [displayed 14 September 2021]. Available at: https://www. perkinelmer.com/content/manuals/gde quantulusinstrumentmanual.pdf

26. Stojković I, Todorović N, Nikolov J, Tenjović B. PSA discriminator influence on ${ }^{222} \mathrm{Rn}$ efficiency detection in waters by liquid scintillation counting. Appl Radiat Isot 2016;112:80 8. doi: 10.1016/j.apradiso.2016.03.020

27. Salonen L. Calibration of the direct LSC method for radon in drinking water: interference from ${ }^{210} \mathrm{~Pb}$ and its progenies accumulated in ${ }^{226} \mathrm{Ra}$ standard solution. Appl Radiat Isot 2010;68:131-8. doi: 10.1016/j.apradiso.2009.08.006

28. Zouridakis N, Ochsenkuhn KM, Savidou A. Determination of uranium and radon in potable water samples. J Environ Radioactiv 2002;61:225-32. doi: 10.1016/s0265931x(01)00125-4
29. Galan Lopez M, Martin Sanchez A, Gómez Escobar V. Application of ultra-low level liquid scintillation to the determination of ${ }^{222} \mathrm{Rn}$ in groundwater. J Radioanal Nucl $\mathrm{Ch} \mathrm{e} \mathrm{m} 2004 ; 261: 631-6$. d o i : 10.1023/B:JRNC.0000037106.78880.d0

30. Council Directive 2013/51/EURATOM of 22 October 2013 laying down requirements for the protection of the health of the general public with regard to radioactive substances in water intended for human consumption [displayed 1 September 2021]. Available at https://eur-lex.europa.eu/ legal-content/EN/TXT/PDF/?uri=CELEX:32013L0051\& from $=\mathrm{EN}$

31. Kinner NE, Malley JrJP, Clement JA, Quern PA, Schell GS, Lessard CE. Effects of sampling technique, storage, cocktails, sources of variation, and extraction on the liquid scintillation technique for radon in water. Environ Sci Technol 1991;25:1165-71. doi: 10.1021/es00018a023

32. Kaihola L, Oikari T, Suontausta J. Ultra-sensitive alpha particle detection in the presence of high beta activity by low-level liquid scintillation spectrometry. In: Cook GT, Harkness DD, MacKenzie AB, Miller BF, Scott EM, editors. Advances in Liquid Scintillation Spectrometry 1994. Tucson (AZ): Radiocarbon Publishers; 1996. p. 301-5.

\section{Utjecaj radija na mjerenje radona u vodi - usporedba monofazne i dvofazne tekućinske scintilacijske spektrometrije}

Točne i precizne metode za mjerenje aktivnosti ${ }^{226} \mathrm{Ra} \mathrm{i}{ }^{222} \mathrm{Rn}$ u pitkim vodama, kao i u površinskim i podzemnim vodama, nužne su kako bi se procijenilo izlaganje zračenju i radiološki rizik za zdravlje stanovništva. Tekućinska scintilacijska spektrometrija (tzv. liquid scintillation counting, krat. LSC) veoma je pogodna metoda za koju je potrebno pripremiti bilo monofazne (homogene) ili dvofazne uzorke. Cilj našega istraživanja bio je usporediti detekcijsku učinkovitost spomenutih metoda na stvarnim uzorcima iz Niške Banje s povišenom koncentracijom aktivnosti ${ }^{222} \mathrm{Rn}$, u koje je dodana otopina standarda ${ }^{226} \mathrm{Ra}$, što je dalo uvid u ponašanje tih uzoraka, njihovu stabilnost i utjecaj ${ }^{226} \mathrm{Ra}$ na mjerenje koncentracije ${ }^{222} \mathrm{Rn}$. Prisutnost ${ }^{226} \mathrm{Ra}$ može se preciznije detektirati u homogenim uzorcima, a dvofazna metoda pouzdanija je pri mjerenju sadržaja ${ }^{222} \mathrm{Rn}$ s manjim ${ }^{226} \mathrm{Ra}$ doprinosom u dobivenim rezultatima. Međutim, u monofaznim uzorcima dobiva se veća točnost pri neizravnom mjerenju koncentracija aktivnosti ${ }^{226} \mathrm{Ra}$. Nakon uspostavljanja radioaktivne ravnoteže između ${ }^{222} \mathrm{Rn} \mathrm{i}{ }^{226} \mathrm{Ra} u$ uzorku, primijećeno je da kokteli koji se ne miješaju s vodom (u dvofaznim uzorcima) imaju ograničeni kapacitet za transfer radijeva potomka ${ }^{222} \mathrm{Rn}$ iz vode u organsku fazu. Također smo zaključili da se uzorci s prirodno povišenim sadržajem ${ }^{222} \mathrm{Rn}$ ne trebaju obogaćivati višim koncentracijama ${ }^{226} \mathrm{Ra}$ od onih pronađenih u stvarnim uzorcima te da je kalibriranje metode s dvofaznim uzorcima izazovno pri mjerenjima koja traju duže vrijeme. Daljnja istraživanja zahtijevaju obogaćivanje znatno nižim koncentracijama ${ }^{226}$ Ra radi dobivanja praktičnih odgovora na pitanja koja proizlaze iz demonstriranih fenomena.

KLJUČNE REČI: ${ }^{222} \mathrm{Rn}$; ${ }^{226} \mathrm{Ra}$; dvofazni uzorak; LSC; monofazni uzorak; Quantulus $1220^{\mathrm{TM}}$; voda 